\title{
Role of Capacity in Understanding Organizational Change in National Sports Federations
}

\begin{abstract}
The aim of this paper is to present an overview of selected organizational theories pertaining to the process of organizational change. The emphasis is made on organizational capacity outlining its relevance in the context of understanding the changes taking place within the National Sports Federations.
\end{abstract}

Keywords: organizational capacity, organizational change, institutional theory, National Sport Federations.

Straipsnio tikslas - atlikti pasirinktų organizacijų teorijų, susijusių su organizacinio pokyčio analizavimu, apžvalgą. Dẻmesys ypač skiriamas organizaciniams pajègumams, demonstruojant jų svarbą analizuojant organizacinị pokytị, vykstantị nacionalinèse sporto federacijose.

Raktiniai žodžiai: organizaciniai pajègumai, organizacinis pokytis, institucinè teorija, nacionalinès sporto federacijos.

\section{Introduction}

The literature of organization theory can provide us with some insights into how political, economic and societal changes were affecting Lithuanian National Sports Federations (NSF). In particular, extant theories of organizational change have much to contribute in this regard as it has been demonstrated in the work of T. Slack and his colleagues (Slack, Hinings, 1992; Kikulis, Slack, Hinings, 1995a; 1995b; Hinings et al., 1996). Their research has made an enormous contribution to our understanding of how sport organizations change. Nevertheless, their investigations were limited to the North American organizations and, for this reason, to relatively stable environments. Moreover, the conceptual frameworks with which they carried out their investigations (Kikulis et al., 1995a; 1995b; Hinings et al., 1996) suffer from similar limitations. The implication, thus, is that neither the theories nor the findings can be blindly applied in attempting to anticipate how Lithuanian sport organizations are responding to the changes taking place around them. Instead, they must be adapted in a way that takes account of the Lithuanian context.

\footnotetext{
Mindaugas GOBIKAS - PhD student at Mykolas Romeris University, Institute of Leadership and Strategic Management, Lithuania. Address: Ateities str. 20, LT-08303, Vilnius, Lithuania. Phone: +37061133911. Email: mindaugasgobikas@gmail.com
}

Vilma ČINGIENE - professor at Mykolas Romeris University, Institute of Leadership and Strategic Management. Address: Ateities str. 20, LT-08303, Vilnius, Lithuania. Email: v.cingiene@mruni.eu 
As is well known to those who study sports management, it is the writings of R. Hinings and R. Greenwood (1988; 1996) and A. Pettigrew (1987) that were most influential in investigations of changes within sport organizations. The applications of these theories have been wide, as well as recent (Shanikat, 2007; Legg, Snelgrove, Wood, 2016; Kitchin, 2017). Contained within them are fully elaborated frameworks for studying and understanding organizational change. To evaluate every aspect of Lithuanian sports organizations touched upon by these theories would be an enormous undertaking and, admittedly, one of questionable utility. As a result, the challenge is to determine which aspects of these theories are likely to provide the greatest contribution to our understanding of how these organizations are being affected.

Thus, it is suggested here that the organizational capacity is the most important consideration within the context of organizational change in Lithuanian NSFs, which presents the problem of research. However, to appreciate why this is the case, the role of capacity within theories of change must be clear.

The object of research is the organizational change in NSFs.

The aim of this paper is to present a brief overview of the broader contours of the organizational change theories; to discuss the concept of organizational capacity in greater detail; and to outline its relevance in the context of understanding the changes taking place within National Sport Federations.

In order to fulfill these objectives an academic literature analysis, theoretical modeling and interpretation methods were applied.

\section{Theories of organizational change}

Several authors (Pettigrew, 1985; Pettigrew, 1987; Slack, Hinings, 1992; Greenwood, Hinings, 1996; Pundzienè, 2004) have acknowledged that organizational change is a highly complex process. As a result, change cannot be studied in a discrete way. A. Pettigrew (1985, p. 1), at the very beginning of his book, talks about the necessity of an all-round examination of the change process:

Beware of the myth of the singular theory of social and organizational change. Look for continuity and change, patterns and idiosyncrasies, the actions of individuals and groups, the role of contexts and structures, the processes of structuring. Give history and social processes the chance to reveal their untidiness.

According to A. O. Alase (2017), using different theoretical perspectives allows one to explain different aspects of the change process and produce a more complete picture of the phenomenon. More specifically, T. Slack and R. Hinings (1992) state that resource dependence model helps to answer the question of why the change occurred. Further, they utilize institutional theory in order to describe the direction that the change took. Similarly, G. Cunningham (2002) proposes an integrative model of organizational change, which includes institutionalism, population ecology, strategic choice and resource dependency theories as its basis. As a result, the two theories-institutional and resource dependency-will be presented in greater detail next, as they both enable to explain the process of organizational adaptation to environmental changes. 
"A resource dependence perspective views the organization as being members of coalitions in a constant state of change" (Sheppard, 1995, p. 29). J. Sheppard also notes that coalitions (groups of claimants) can be internal and external to the organization and each group can have some power over the organization. Organizations are unable to generate the variety and amount of resources they need for survival; consequently, they become dependent on their environment for those resources. From this perspective, according to T. Slack and R. Hinings (1992, p. 116), "organizations change either by adapting to changes in the resource environment or by acting to change the environment".

Resource dependence model helps to explain the difficulties that sports organizations in Lithuania are facing. Especially it could be stated that changes affecting the National Sports Federations because the majority of their entire budget comes from the state subsidies.

However, as stated earlier, it is an institutional theory that helps to predict the direction of the occurring change. The external pressures that the environment puts on organizations are explained by a number of authors (Meyer, Rowan, 1977; DiMaggio, Powell, 1983; Zucker, 1987; Slack, Hinings, 1992) through institutional theory. Institutionalization is described as a process through which "organizations are driven to incorporate the practices and procedures defined by prevailing rationalized concepts of organizational work and institutionalized in society" (Meyer, Rowan, 1977, p. 340). Legitimacy and not efficacy are seen here as the key element of success (Meyer, Rowan, 1977; DiMaggio, Powell, 1983).
An outcome of institutional pressures is the homogenization of organizations, which P. DiMaggio and W. Powell (1983) refer to as institutional isomorphism. Accordingly, there are three isomorphic processes: coercive, mimetic, and normative. Coercive isomorphism is a result of political, cultural or market influences that lead to the implementation of appropriate and legitimate changes. Mimetic isomorphism derives from uncertainty. In this case, organizations model themselves on other organizations, which are perceived as more successful. Normative isomorphism is bound up with professionalization in organizations. Various kinds of professionals within an organization, due to formal education and the filtering process of personnel, have much in common with their professional counterparts in other organizations.

Institutional isomorphism should be distinct in Lithuanian NSFs, as they could try to 'copy' other, more successful sports organizations (quite possible those of the western countries) or hire new personnel. H. Haveman (1992) states that change may prove beneficial only if it builds on established routines and competences. However, institutional isomorphism should be carefully considered in the context of emerging economy countries, as P. DiMaggio and W. Powell (1983) state that institutional isomorphism becomes apparent only in well-established organizational fields. It is arguable that Lithuania and other countries in emerging economies exhibit well-developed and stable organizational environments yet.

As noted earlier, environmental changes in Lithuania are pressing organizations to adapt. However, all organizations are different: they exhibit different 
capabilities, they acquire different resources, and they display different actions. Thus, it is critical to look at the organization's internal actors, namely their response to institutional prescriptions.

\section{Theoretical framework for studying change}

Several studies have revealed the importance and role of organizational actors in the change process as they enable and constrain the change (Greenwood, Hinings, 1996; Cunningham, 2002), explain sources of commitment and resistance (Slack, Hinings, 1992), and adjust social conditions to meet people's ends (Pettigrew, 1987). In order to understand the change process, the internal dynamics in organizations has to be emphasized; also, their response to external pressures, along with their influence and role in the change process must be examined. As E. Wee and S. Taylor (2017) argue, changes are most likely to originate from the lower level of the organization.

A. Pettigrew (1987), R. Greenwood and R. Hinings (1996) as well as G. Cunningham (2002) provide similar theoretical frameworks that should guide the investigation of the change. All three frameworks are based on the exploration of exogenous and endogenous dynamics. The understanding of change comes from the examination of these two sources and, in particular, an understanding of their interrelations.

A. Pettigrew (1987) breaks down the change into three categories-content, context, and process-and explains how examining them helps the researcher to understand the patterns and dynamics of change and to answer the questions of 'what', 'why', and 'how'. Context is divided into outer (social, economic, political, and competitive environment in which the firm operates) and inner (structure, culture, and politics within the firm through which ideas for change have to proceed) and the interaction between the two constitutes the process. The result leads to the content, which, according to A. Pettigrew (p. 657), "refers to the particular areas of transformation under examination".

R. Greenwood and R. Hinings (1996, p. 1041) attempt to demonstrate "how the external processes of deinstitutionalization have to be understood (organizations-in-sectors) together with the internal dynamics of interpretation, adoption, and rejection by the individual organization" as they emphasize and explain external and internal actors of the change process in more detail. Their model concerns five key factors: context, interests, values, power, and capacity.

Correspondingly, G. Cunningham (2002) incorporates the framework of R. Greenwood and R. Hinings (1996) with the addition of several elements. He sustains the notion of reliance on multiple theoretical tools upon conducting the research of organizational change. "... if we rely on a single theory ... we have taken a tunnel-vision approach to our research" states G. Cunningham (2002, p. 283) and forms his model around seven key components: deinstitutionalization, inertia/ entropy, commitments, capacity, resource dependence, power, and alternatives.

Exogenous dynamics, which refer to market and institutional pressures, create the context for change. "Within emerging economies, the market context is characterized by a move towards the ownership 
of private property, an ethic of individualism, and the quest for profit (Mauws, Phillips, 1997; Shanikat, 2007).

The institutional context, as mentioned earlier, is concerned with the systems surrounding organizations that shape social and organizational behaviors. Agencies, such as the state and other large organizations, exert pressure to adopt socially prescribed structures that are ultimately defined as appropriate and necessary ways of organizing and operating.

Similarly to aforementioned, G. Cunningham (2002) distinguishes political, functional and social pressures as external forces that lead deinstitutionalization of current organizational practices.

According to R. Greenwood and R. Hinings (1996) and G. Cunningham (2002), organizational actors will ultimately decide the change process. Free markets and new institutional contexts will ignite the change and create the environment for reconstruction, but it is the internal dynamics, "the response of the individual organization to pressure in the institutional field" (p. 1032) that furthers or constrains the change. As R. Greenwood and R. Hinings conclude (Ibid.) "the role of the intraorganizational dynamics in accepting or rejecting institutionalized practices is critical". Intraorganizational dynamics are a combination of precipitating and enabling dynamics or, as G. Cunningham (2002) labeled them, moderating factors.

The central focus in studying organizational response to institutional pressures is on precipitating dynamics, for those include interests and value commitments of organizations. Interests concern the allocation of scarce and valued organizational resources and "a potential pres- sure for change and/or inertia, therefore, is the extent to which groups are dissatisfied with how their interests are accommodated within an organization" (Greenwood, Hinings, 1996, p. 1035).

However, "intense pressure for change arising from dissatisfaction with accommodation of interests will not lead to radical change unless dissatisfied groups recognize the connection between the prevailing template (which shapes the distribution of privilege and disadvantage) and their position of disadvantage" (Greenwood, Hinings, 1996, p. 1035). Thus, R. Greenwood and R. Hinings identify four patterns of value commitments: the status quogroups commit to the prevailing institutional template; indifferent commitmentgroups neither commit to nor oppose the prevailing institutional template; competitive commitment-some groups support the prevailing institutional template, while others prefer an alternative one; and reformative commitment-groups oppose the prevailing institutional template. Thus, "radical change will occur only if interests become associated with a competitive or reformative pattern of value commitment" (Greenwood, Hinings, 1996, p. 1036). A. Pettigrew (1987, p. 659) also sees interests and values not as neutral or functional constructs, but as "capable of serving to protect the interests of dominant groups".

The discussion of R. Greenwood and R. Hinings' (1996) theoretical framework follows with the inclusion of comments on enabling dynamics, since only "conjunction with an appropriate 'capacity for action' and supportive power dependencies" (p. 1037) will prompt a radical change process to move forward.

The concept of power is critical in organizational change studies since "the 
operation of values and interests can be conceptualized and understood only in relation to the different power of groups" (Greenwood, Hinings, 1996, p. 1038). Both the market context and the institutional context affect the distribution of power. The resource dependence model describes the market pressures under which some groups gain advantage through newly arisen circumstances. On the other hand, as R. Greenwood and R. Hinings (1996, p. 1039) note, the "institutional context might nullify pressures from the market context". As a result, changes in organizational structure will occur "only if the dominant coalition recognizes the weaknesses of existing template arrangements and is aware of potential alternatives" (Greenwood, Hinings, 1996, p. 1039).

A. Pettigrew (1987) and G. Cunningham (2002) also support the importance of the power relations within the organization. They state that two types of power utility correspond within change processes: power can either defeat or prevent competition in a strategic choice or change process.

The final intraorganizational dynamic defined by R. Greenwood and R. Hinings (1996) is capacity. Accordingly, capacity has three aspects: i) sufficient understanding of the new conceptual destination; ii) the skills and competencies required to function in that new destination, and iii) the ability to manage how to get to that destination. An important characteristic of organizational capacity emphasized by R. Greenwood and R. Hinings is its ability to influence the speed of the change process: "a clear understanding of the new destination and of how to get to that destination may give an organization the confidence to push ahead rapidly with change. On the other hand, lack of clarity and lack of expertise may promote lack of sureness and slower, almost experimental steps" (p. 1040).

A. Pettigrew (1987) also recognized leadership as one of the most important factors of the organizational change process. His study of Imperial Chemical Industries (ICI) revealed the key aspects of the leadership role during the transformational period as the top decision-makers had to orchestrate "an educational process-trying to open up ICI to change" (p. 666) and tried to "construct a climate for change around the performance difficulties" (p. 665).

The next section of this paper will present R. Greenwood and R. Hinings' (1996) theoretical model's relevance in the context of understanding the changes taking place within Lithuanian NSFs. Particular emphasis will be placed on the importance of organizational capacity.

\section{Organizational change in Lithuanian NSFs}

M. W. Peng (2000) states that two distinct types of reforms and transitions have emerged in the past two decades: the "big bang" type, in which rapid, all-round reforms took place in a short period of time and "gradualist," which is characterized by incremental reforms occurring over time. This is similar to what R. Greenwood and R. Hinings (1996) label as "radical" and "convergent" change in their theoretical framework for the study of former. According to M. W. Peng (2000), Central and Eastern European countries (with Lithuania among them) adopted the "big 
bang" approach. Thus, it would appear that R. Greenwood and R. Hinings' (1996) model should serve well in the context of this research. In addition, Lithuanian scholars stress the need for the research of this nature, as they see the radical change processes to be more appropriate and more relevant to the current situation in Lithuania (Jucevičius, 1996).

As noted earlier, institutional pressures and market signals create the context for change. In a planned economy, the government performs the role of the market. The state oversees all organizational assets, owns enterprises, distributes funds, etc., and, thus, there is neither incentive nor environment for business relations. However, in a transition from a centrally planned to a marked-led economy, there is an impact of changes in organizations' operational autonomy.

The emergence of a new governmental system brought new managerial practices to Lithuania. Private ownership has been allowed and individual initiatives have been encouraged. This brought a change to the degree to which the resources available to organizations depended on their actions. In the case of the NSFs in Lithuania, significantly decreased state funding, as well as increased demand for added and new activities, has required organizations to search for new sources of revenues.

It is important to note here that the institutional context might take the leading role in starting and steering the change process in Lithuania. Z. Lydeka (2000) states that the market's self-organization in the transformation period was not capable of overcoming deep transformational processes. According to him, the interference of the government was critical.
On the other hand, the questioning of businessmen in Lithuania showed that the legal base of Lithuania needed considerable refinements (Žukauskas, Stanionyte, 2000). This also applies to sports organizations as sports organizations with similar profiles in Lithuania can be established as associations, public establishments, individual enterprises or stock companies. Such lack of clarity in organizational statutes created confusion with respect to organizations' accountability and tax privileges. As the research on the role of local authorities in developing sports policy in Lithuania showed (Čingienè, Motiejunaite, 1998; Čingienè, Gineikienè, 2013; Čingienè, 2014) that the state's sports organizations lacked clearly defined organizational strategies; their regulations did not reflect structural arrangements; the financial criteria for distribution of funds were not clear.

This leads to the conclusion that in the context of rapid changes the obscurity of 'how to proceed further' penetrated all the state members. R. Greenwood and R. Hinings (1996) argue that "in less welldeveloped sectors ... the existence of leading organizations is less clear ... as a consequence, there is no stipulated template for organizing, and thus pressures for conformity are much less pronounced" (p. 1029). In this case, the variety of organizational designs could be justified by the sector's immaturity, as could be the case in emerging economy countries. It could be argued that most sectors in countries with newly established forms of government are much less underdeveloped.

J. Allmendinger and R. Hackman's research (1996) on German symphony orchestras, which was conducted in the former East Germany, also supports this 
supposition. The changes in the politicaleconomic environment they described in East Germany in 1990 were very similar to those of Lithuania. One of the conclusions showed that the government was not supportive of its once owned organizations and did not buffer them during the national-level changes. This shows that organizations were left to struggle in a turbulent environment of major reconstructions with no help or guidance and were forced to rely much on their own capabilities. As a consequence, it could be stated that rapid political and economic changes originated the context for change and invoked organizations to adapt.

As was explained earlier, capacity and leadership were the enabling components of the successful implementation of the strategic change process. In the state of uncertainty, internal actors of organizations seemed to be the key factors to successful adaptation. J. Allmedinger and R. Hackman's (1996) research showed that capacity and knowledgeable leadership were the key components of successfully operating organizations. Since organizations were not strongly supported by the state, it was good and innovative leadership, as well as proper organizational capacities that separated successful and unsuccessful organizations. Similarly, research conducted in Lithuania (Pundzienè, Duobiené, 2006; Pundziené, Alonderiené, Buožiūté, 2007) provided interesting insights regarding communication competence of managers and entrepreneurial aspects of organization CEOs. Arguably the characteristics of organizational capacity, it was discovered that organizations with higher levels of those characteristics displayed both better success and better reaction to organizational change.
J. Amis (2004) also suggests that capacity plays an influential role in the change process. Organizations will have the possibility for changing if their leaders are able to create a vision of the future and to communicate that vision to other members. Lack of technical and behavioral expertise makes organizational change very unlikely to happen.

Significantly, as reinforced by the research done on youth soccer organizations (Legg et al., 2016), organizational capacity was found to be a key factor in constraining successful change in sport organizations.

Thus, it appears that organizations' capacity-leadership, knowledge, and abilities-should take the leading role in Lithuanian NSFs' change processes. The examination of organizational capacities should allow us to gain the most meaningful insight into an ongoing transformation process.

\section{Conclusions}

Almost thirty years ago political events started a period of radical changes in Lithuania. The shift from a centrally planned economy to a market-led economy created a capitalistic environment. Organizational theories provide insights into understanding the organizational change process through the emphasis of a combination of the external conditions and the society's perceptions of them. Resource dependence theories provide meaningful insights into how organizations adapt to their environment in order to obtain necessary resources. An application of such perspective is particularly relevant to the post-soviet context, which enabled the 
emergence of new revenue streams and possibilities.

Institutional theories, through the concepts of rationalization and incorporation of best practices, can help a further explanation of the organizational change process. Mainly by analyzing legitimacy, as well as homogenization of the entire sector of organizations, institutional theory provides interesting answers regarding the direction of occurring change. Nevertheless, it is of the utmost importance to include internal organizational dynamics upon trying to examine organizational change. Tightly interrelated internal interests, values, power dependencies and capabilities dictate the direction and dynamics of the organizational change process.

Organizational capacity, which is regarded as the ability of the organization and its members to implement and manage new ways of operating, is seen as the principal factor in the entire process. Organizational changes undergoing in Lithuanian National Sports Federations should be analyzed with close examination of organizational capabilities.

\section{References}

1. Alase, A. O. (2017). The Tasks of Reviewing and Finding the Right Organizational Change Theory // International Journal of Educational Leadership and Management. Vol. 5, No. 2, pp. 198-215. doi: 10.17853/ijelm.2017.2631.

2. Allmedinger, J., Hackman, R. (1996). Organizations in Changing Environments: The Case of East German Symphony Orchestras // Administrative Science Quarterly. Vol. 41, pp. 337-369. doi: 10.2307/2393935.

3. Amis, J. (2004). Strategic Change and Role of Interests, Power and Organizational Capacity // Journal of Sport Management. Vol. 18, No. 2, pp. 158-198. doi: https://doi.org/10.1123/ jsm.18.2.158.

4. Čingienè, V., Motiejūnaitè, D. (1998). Role of Local Authorities in Developing Sports Policy: The Case of Lithuania. Sport in the City. Conference conducted in Sheffield, England.

5. Čingienè, V., Gineikienè, L. (2013). Lietuvos sporto mokymo itstaigu veiklos auditas/ Performance audit in sport education centres // Ekonomika ir vadyba: aktualijos ir perspektyvos. Vol. 3, No. 31, pp. 121-132.

6. Čingienè, V. (2014). Veiklos audito praktika vertinant sportininkų ugdymo centrų veiklos patirtị / Performance audit practice evaluating the activity content of the sports education centres // Sporto mokslas. Vol. 4, No. 78, pp. $40-49$.
7. Cunningham, G. (2002). Removing the Blinders: Toward an Integrative Model of Organizational Change in Sport and Physical Activity // Quest. Vol. 54, pp. 276-291. doi: https://doi.org/10.108 0/00336297.2002.10491779

8. DiMaggio, P., Powell, W. (1983). The Iron Cage Revisited: Institutional Isomorphism and Collective Rationality in Organizational Fields // American Sociological Review. Vol. 48, pp. 147-160. doi: 10.2307/2095101.

9. Greenwood, R., Hinings, R. (1988). Organizational Design Types, Tracks and the Dynamics of Strategic Change // Organization Studies. Vol. 9, pp. 293-316.

10. Greenwood, R., Hinings, R. (1996). Understanding Radical Organizational Change: Bringing Together the Old and the New Institutionalism // Academy of Management Review. Vol. 21, pp. 1022-1054. doi: $10.2307 / 259163$.

11. Haveman, H. (1992). Between a Rock and a Hard Place: Organizational Change and Performance under Conditions of Fundamental Environmental Transformation // Administrative Science Quarterly. Vol. 37, pp. 48-75. doi: 10.2307/2393533.

12. Hinings, R., Thibault, L., Slack, T., Kikulis, L. (1996). Values and organizational structure // Human relations. Vol. 49, pp. 885-916. 
13. Jucevičius, R. (1996). Organizacijos transformavimo koncepcijų analizè // Organizacijų vadyba: sisteminiai tyrimai. Vol. 3, pp. 61-73.

14. Kikulis, L., Slack, T., Hinings, R. (1992). Institutionally Specific Design Archetypes: A Framework for Understanding Change in National Sport Organizations // International Review for the Sociology of Sport. Vol. 27, pp. 343-370. doi: https://doi. org/10.1177/101269029202700405

15. Kikulis, L., Slack, T., Hinings, R. (1995). SectorSpecific Patterns of Organizational Design Change // Journal of Management Studies. Vol. 32, pp. 67-100. doi: 10.1111/j.1467-6486.1995. tb00646.x

16. Kitchin, P. (2017). Using a Dual-sited Organizational Ethnography to Examine Change within and between Community Sport Organizations // Managing Sport and Leisure. Vol. 22, No. 3, pp. 181-196. doi: https://doi.org/ 10.1080/23750472.2017.1417739

17. Legg, J., Snelgrove, R., Wood, L. (2016). Modifying Tradition: Examining Organizational Change in Youth Sport // Journal of Sport Management. Vol. 30, pp. 369-381. doi: 10.1123/jsm.2015-0075.

18. Lydeka, Z. (2000). The Transformation of an Economic System // Organizaciju vadyba: sisteminiai tyrimai. Vol. 15, pp. 129-139.

19. Mayer, J., Rowan, B. (1977). Institutionalized Organizations: Formal Structure as Myth and Ceremony // American Journal of Society. Vol. 83, pp. 340-363. doi: https://doi. org/10.1086/226550.

20. Peng, M.W. (2000). Business Strategies in Transition Economies. - London: Sage Publications, Inc.

21. Pettigrew, A. (1985). The Awakening Giant: Continuity and Change in ICI. - Oxford: Blackwell.

22. Pettigrew, A. (1987). Context and Action in the Transformation of the Firm // Journal of Management Studies. Vol. 24, pp. 649-670. doi: https://doi.org/10.1111/j.1467-6486.1987. tb00467.x
23. Pundzienė, A. (2004). Managing Organisational Change // Organizacijų vadyba: sisteminiai tyrimai. Vol. 29, pp. 163-172.

24. Pundzienè, A., Duobienè, J. (2006). CEOs' Entrepreneurship in Relation to Reaction to Organizational Change // Engineering Economics. Vol. 2, No. 47, pp. 91-98.

25. Pudzienè, A., Alonderienè, R., Buožiūtè, S. (2007). Managers' Change Communication Links with the Success of the Organisational Change // Engineering Economics. Vol. 4, No. 54, pp. 61-69.

26. Shanikat, M. (2007). Understanding Organizational Change in the Privatized Enterprise: Case Study of Jordan Telecom // EBS Review. Vol. 22, No. 1, pp. 42-58. doi: https:// trove.nla.gov.au/version/190060857

27. Sheppard, J. (1995). A Resource Dependence Approach to Organizational Failure // Social Science Research. Vol. 24, pp. 28-62. doi: https://doi.org/10.1006/ssre.1995.1002

28. Slack, T., Hinings, B. (1992). Understanding Change in National Sport Organizations: An Integration of Theoretical Perspectives // Journal of Sport Management. Vol. 6, pp. 114132. doi: https://doi.org/10.1123/jsm.6.2.114

29. Mauws, M., Phillips, N. (1997). The Institutional Requisites of Capitalism. In A. Ullmann \& A. Lewis (Eds.), Privatization and Entrepreneurship: The Managerial Challenge in Central and Eastern Europe (pp. 45-60). - New York, NY: International Business Press.

30. Wee, E., S. Taylor (2017). Attention to Change: A Multilevel Theory on the Process of Emergent Continuous Organizational Change // Journal of Applied Psychology. Vol. 103, No. 1, pp. 1-13. doi: 10.1037/apl0000261.

31. Žukauskas, P., Stanionytè, L. (2000). Tiesioginių užsienio investicijų klimato Baltijos šalyse palyginamoji analizè // Organizaciju vadyba: sisteminiai tyrimai. Vol. 15, pp. 181-199.

32. Zucker, L. (1987). Institutional Theories of Organization // Annual Review of Sociology. Vol. 13, pp. 443-464. Doi: https://doi. org/10.1146/annurev.so.13.080187.002303

The paper submitted: May 14, 2019

Prepared for publication: December 10, 2019 


\section{Mindaugas GOBIKAS, Vilma ČINGIENĖ \\ ORGANIZACINIỤ PAJĖGUMỤ VAIDMUO TIRIANT ORGANIZACINĮ POKYTĮ LIETUVOS SPORTO FEDERACIJOSE}

\section{S a n t r a u a}

Ivarios organizacinio pokyčio teorijos pateikia svarių ižvalgų apie politinių, ekonominių ir socialinių pokyčių ittaką Lietuvos sporto federacijų veiklai. Užsienio autorių tyrimai išsamiai nagrinèja sporto organizacijų kaitą ir pokytị sąlygojančius procesus. Tačiau, reikia pabrèžti, kad dauguma šių tyrimų atlikti Šiaurès Amerikos organizacijose ir kartu santykinai stabilioje aplinkoje. Tuo tarpu Lietuvos sporto organizacijų aplinka pasižymi labiau radikaliomis permainomis, kurias reikia atitinkamai įvertinti, analizuojant organizacini pokytị. Todèl pasitelkiant organizacinio pokyčio tyrinejjimo modelius, svarbiausia išskirti esminius šių teorijų aspektus, atliekančius pagrindinị vaidmenị pokyčio procese.

Šiame straipsnyje teigiama, kad organizaciniai pajègumai atlieka pagrindinị vaidmenị organizacinio pokyčio procese.

Šio straipsnio tyrimo objektas - organizacinis pokytis Lietuvos sporto federacijose.

Straipsnio tikslai - atlikti organizacinị pokyti nagrinejjančių teorijų apžvalgą, išsamiau aptarti organizacinių pajègumų sąvoką ir išanalizuoti organizacinių pajègumų aktualumą tiriant organizacinị pokyti Lietuvos sporto federacijose.
Pirmoje straipsnio dalyje atskleidžiama institucinès ir išteklių priklausomybès teorijų svarba organizacinio pokyčio tyrimuose. Atsižvelgiant i pokyčio proceso kompleksiškumą, akcentuojamas tiek išorinès, tiek vidinès organizacijų aplinkos vaidmuo. Autoriai (Greenwood ir Hinings, 1996) išskiria tokius vidinius organizacijos veiksnius, kaip antai: interesai, vertybès, galia ir organizaciniai pajègumai, ir parodo, kaip šie veiksniai igalina ir pagreitina pokyčio procesą.

Antroje straipsnio dalyje pristatomi politiniai, ekonominiai ir socialiniai pokyčiai, su kuriais susiduria Lietuvos sporto federacijos. Be išorinių veiksnių, diskutuojama apie pagrindinių vidinès organizacijos dinamikos veiksnių ittaką ir pristatoma organizacinių pajègumų svarba. Tyrimai atskleidžia (Allmedinger ir Hackman, 1996; Pundzienè ir Duobienè, 2006; Pundzienè ir kt., 2007), kad vadovu lyderiavimas, vadovų komunikacijos kompetencija ir vadovų antrepreneriškumas atlieka pagrindinị vaidmenị sèkmingai igyvendinant organizacinị pokyti. Daroma išvada, kad Lietuvos sporto federacijose vykstantys organizaciniai pokyčiai turètú būti analizuojami glaudžiai tiriant ir organizacinius pajègumus. 